University of Nebraska - Lincoln

DigitalCommons@University of Nebraska - Lincoln

\title{
Protocols for Nationally Coordinated Laboratory and Field Research on Manure Nitrogen Mineralization
}

C. W. Honeycutt

USDA-ARS, wayne.honeycutt@ars.usda.gov

T. S. Griffin

USDA-ARS

Brian J. Wienhold

USDA-ARS, Brian.Wienhold@ars.usda.gov

Bahman Eghball

USDA-ARS, beghball1@unl.edu

S. L. Albrecht

USDA-ARS

See next page for additional authors

Follow this and additional works at: https://digitalcommons.unl.edu/usdaarsfacpub

Part of the Agricultural Science Commons

Honeycutt, C. W.; Griffin, T. S.; Wienhold, Brian J.; Eghball, Bahman; Albrecht, S. L.; Powell, J. M.; Woodbury, B. L.; Sistani, K. R.; Hubbard, R. K.; Torbert, H. A.; Eigenberg, R. A.; Wright, R. J.; and Jawson, M. D., "Protocols for Nationally Coordinated Laboratory and Field Research on Manure Nitrogen Mineralization" (2005). Publications from USDA-ARS / UNL Faculty. 609.

https://digitalcommons.unl.edu/usdaarsfacpub/609

This Article is brought to you for free and open access by the U.S. Department of Agriculture: Agricultural Research Service, Lincoln, Nebraska at DigitalCommons@University of Nebraska - Lincoln. It has been accepted for inclusion in Publications from USDA-ARS / UNL Faculty by an authorized administrator of DigitalCommons@University of Nebraska - Lincoln. 


\section{Authors}

C. W. Honeycutt, T. S. Griffin, Brian J. Wienhold, Bahman Eghball, S. L. Albrecht, J. M. Powell, B. L. Woodbury, K. R. Sistani, R. K. Hubbard, H. A. Torbert, R. A. Eigenberg, R. J. Wright, and M. D. Jawson 


\title{
Protocols for Nationally Coordinated Laboratory and Field Research on Manure Nitrogen Mineralization
}

\author{
C. W. Honeycutt and T. S. Griffin \\ USDA-ARS, Orono, ME, USA
}

B. J. Wienhold and B. Eghball

USDA-ARS, Lincoln, NE, USA

S. L. Albrecht

USDA-ARS, Pendleton, OR, USA

J. M. Powell

USDA-ARS, Madison, WI, USA

B. L. Woodbury

USDA-ARS, Clay Center, NE, USA

K. R. Sistani

USDA-ARS, Mississippi State, MS, USA

R. K. Hubbard

USDA-ARS, Tifton, GA, USA

H. A. Torbert

USDA-ARS, Auburn, AL, USA

Received 6 August 2004, Accepted 23 December 2004

Address correspondence to C. W. Honeycutt, USDA Agricultural Research Service, New England Plant, Soil, and Water Laboratory, Orono, Maine 04469, USA. Tel.: 207-581-3363; Fax: 207-866-0464; E-mail: Wayne.Honeycutt@ars.usda. gov 


\author{
R. A. Eigenberg \\ USDA-ARS, Clay Center, NE, USA \\ R. J. Wright and M. D. Jawson \\ USDA-ARS, Beltsville, MD, USA
}

\begin{abstract}
The National Program structure of USDA-ARS provides an opportunity to coordinate research on problems of national and global significance. A team of USDA-ARS scientists is conducting nationally coordinated research to develop predictions of manure $\mathrm{N}$ availability to protect water quality and improve farm solvency. Experimental design and research protocols were developed and used in common across all participating locations. Laboratory incubations are conducted at each location with a minimum of three soils, three temperatures, two wetting/drying regimes, and two manure treatments. A soil from the central United States (Catlin silt loam, fine-silty, mixed, superactive, mesic Oxyaquic Argiudoll) is used as an internal reference across all locations. Incubation data are compiled across locations to develop generalized predictions of manure nitrogen mineralization (Nmin). Field validation data are then obtained by monitoring nitrogen $(\mathrm{N})$ transformations in manure-amended soil cores equipped with anion exchange resin to capture leached nitrate. This field data will be used to compare laboratory-based predictions with field observations of Nmin in each soil, climatic zone, and manure type represented. A Decision Support System will then be developed for predicting manure N mineralization across ranges in soil, climate, and manure composition. Protocols used by this research team are provided to 1) document the procedures used and 2) offer others detailed information for conducting research on nutrient transformation processes involving collaboration across locations or complementary research between laboratory and field environments.
\end{abstract}

Keywords: USDA-ARS, national programs, Nmin team, manure N, nitrate, incubation method, water quality

\title{
INTRODUCTION
}

Approximately 99.3 million cattle (Bos taurus), 7.6 million sheep (Ovis aries) and goats (Capra hircus), 8.4 billion poultry (Gallus gallus), and 59.9 million swine (Sus scrofa) are produced annually in the United States, with a total value exceeding $\$ 98.8$ billion (USDA Census of Agriculture, 1997). Manure generated from these industries is estimated to exceed $834,000 \mathrm{Mg}$ of dry matter per day. With nitrogen $(\mathrm{N})$ concentrations ranging from approximately $15-55 \mathrm{~kg} \mathrm{~N} \mathrm{Mg}^{-1}$ dry manure (Griffin et al., 2003), this means approximately $12,500-45,900 \mathrm{Mg}$ of manure-derived $\mathrm{N}$ is produced each day. Concurrently, the land base available for manure application continues to decrease due to urban 
sprawl and other factors. Management practices must be developed that optimize recycling of manure-derived $\mathrm{N}$ to crops, while minimizing adverse environmental consequences of manure application to cropland. Development of these practices is hindered by inabilities to quantifiably predict the impacts of soil properties, manure composition, and climate on manure $\mathrm{N}$ availability.

A team of United States Department of Agriculture, Agricultural Research Service (USDA-ARS) scientists has been organized to address these issues in a nationally coordinated research project. The study represents increased emphasis by USDA-ARS for national research collaborations to solve problems of national/global importance, and is, therefore, conducted within the USDA-ARS Manure and Byproduct Utilization National Program (http://www.ars.usda.gov/research/programs/htm). The objective was to develop, validate, and employ predictive relationships that quantify the impacts of key soil, environmental, and soil $\mathrm{X}$ environmental factors on manure $\mathrm{N}$ mineralization $(\mathrm{Nmin})$. Accurate predictions of manure $\mathrm{N}$ transformation dynamics would promote efficient, environmentally sustainable use of this resource in crop production. The research team's overall approach is to characterize selected agricultural soils and manures from each participant's location; conduct laboratory incubation studies across a range of soils, manures, and controlled climatic parameters; compile all laboratory data to develop generalized predictions of manure Nmin; and to validate Nmin predictions under field conditions across manures, soils, and environments.

In conducting complementary studies across multiple laboratories, explicit planning is paramount to a project's success. Not only does information available in the literature need to be incorporated into the study design, but detailed procedures and examples should be provided to each participant because individual interpretations of common words or phrases can vary. The details developed by scientists conducting this project are provided to 1) document the procedures used and 2) offer others a protocol for conducting research on nutrient transformation processes involving collaboration across locations or complementary research between field and laboratory environments. Recognizing different objectives will require protocol alteration, these procedures are offered as initial guidelines amenable to appropriate modification for other studies.

\section{LABORATORY INCUBATION STUDY PROTOCOL}

The following represent the "Core" treatments and procedures to be followed by all participants to provide a minimum dataset. Additional treatments, sample dates, etc., may be included at the discretion of each scientist. 


\section{Treatments}

\section{Overall Design}

Core Treatments consist of three soils Xthree constant temperatures Xtwo wetting/drying regimes Xtwo manure additions (with and without) Xthree replications in a factorial arrangement. The study is conducted to acquire data on a minimum of five sample dates, to include the day of manure application and at least four wetting/drying cycles. Total minimum experimental units $=108$.

\section{Soils and Manures}

The experimental design allows incubation studies to be conducted at all locations wishing to participate, because each uses their own soils. Each location uses a minimum of two "local" soils plus a Catlin silt loam (fine-silty, mixed, superactive, mesic Oxyaquic Argiudoll) from Champagne, IL. If possible, the two "local" soils should have significantly different textures. Each local soil should also be representative of an important agricultural soil to which manure may be applied. However, to the extent possible, soil should be used that has not received manure in the last 10 years. The Catlin silt loam serves as a standard for comparing unamended soil Nmin across participating laboratories. Manures are selected at the discretion of each participant, but should represent important or potentially important sources for that location. Soils, manures, and selected climatic parameters characterizing each participating location are provided in Table 1.

\section{Environmental Parameters}

\section{Temperature}

Three constant temperature treatments are selected and maintained throughout the incubation study. Temperatures are selected to reflect local conditions during the season when manure is applied to soil and are chosen from one of the following regimes: a) 11,18 , and $25^{\circ} \mathrm{C}$; b) 18,25 , and $32^{\circ} \mathrm{C}$; or c) 25,32 , and $39^{\circ} \mathrm{C}$. In this way, participants from cooler climates may select regime a, participants from hotter climates may select regime c, and data collected at $25^{\circ} \mathrm{C}$ can be directly compared across all locations.

\section{Wetting/Drying Regimes}

Both of the following wetting/drying regimes are used: a) maintain soil at constant $60 \%$ water-filled pore space (WFPS), and b) cycle soils from $60 \%$ WFPS to $30 \%$ WFPS for a minimum of four cycles. Use of the WFPS concept avoids logistical difficulties of maintaining different soils at a given water potential and is widely applicable across soils for establishing optimal 
Table 1. Soils, manures, and environmental parameters of participating locations

\begin{tabular}{|c|c|c|c|c|}
\hline Location & $\begin{array}{c}\text { Mean annual } \\
\text { temperature } \\
\left({ }^{\circ} \mathrm{C}\right)\end{array}$ & $\begin{array}{l}\text { Mean annual } \\
\text { precipitation } \\
\quad(\mathrm{mm})\end{array}$ & Manure & Soil great group \\
\hline Orono, ME & 5.2 & 993 & Dairy, Swine & Haplorthod \\
\hline $\begin{array}{l}\text { Mississippi } \\
\text { State, MS }\end{array}$ & 17.7 & 1453 & Poultry & Paleudult \\
\hline Auburn, AL & 16.7 & 1397 & $\begin{array}{r}\text { Poultry, } \\
\text { Dairy }\end{array}$ & Paleudult \\
\hline Madison, WI & 7.5 & 927 & Dairy & $\begin{array}{l}\text { Argiudoll } \\
\text { Hapludalf } \\
\text { Glossudalf } \\
\text { Glossoboralf }\end{array}$ \\
\hline $\begin{array}{l}\text { Lincoln and Clay } \\
\text { Center, NE }\end{array}$ & 10.9 & 767 & Beef Swine & $\begin{array}{l}\text { Argiudoll } \\
\text { Ustipsamment }\end{array}$ \\
\hline Pendleton, OR & 10.2 & 439 & Beef & $\begin{array}{l}\text { Haploxeroll } \\
\text { Haplocalcid }\end{array}$ \\
\hline Champaign, IL & 10.9 & 1041 & All & Argiudoll \\
\hline
\end{tabular}

aerobic microbial activity and minimizing denitrification losses (Linn and Doran, 1984).

\section{Procedures}

Preparations

Sample the surface $15 \mathrm{~cm}$ of soils to be used in the study and determine their bulk density following established methods described by Grossman and Reinsch (2002).

Air-dry the soil samples not used for bulk density determination. Pass airdried soil through a sieve with $2 \mathrm{~mm}$ diameter openings.

Label and determine the empty weights of the appropriate number of wide-mouth, 2-L canning jars (without lids). Appropriate number will depend upon specific treatments. The number required for the Core study is 108. Mark each jar to indicate the soil level that will provide the appropriate bulk density of soil to be added. This can be done by adding a volume of water (corresponding to the soil's target bulk density) to the jar and marking the water level meniscus (e.g., the Catlin silt loam has a bulk density of $1.2 \mathrm{~g} \mathrm{~cm}^{-3}$, therefore add $250 / 1.2=208 \mathrm{~mL}$ of water).

Determine gravimetric water content of each soil and manure (oven-dry at $105^{\circ} \mathrm{C}$ until constant weight is maintained, generally reached in $24-48 \mathrm{~h}$, but may vary due to differences in ovens, humidity, initial soil water content, etc.). 
Pre-incubation

Weigh $250.0 \mathrm{~g}$ (oven-dry equivalent) sieved soil into wide-mouth, 2-L canning jars. Adjust the water content of each soil to 50\% WFPS with a plant mister using distilled water. Mix well. (NOTE: If you plan to add to the Core study by monitoring $\mathrm{CO}_{2}$ as an indicator of microbial activity, then you should use $\mathrm{CO}_{2}$-free distilled water throughout the study. $\mathrm{CO}_{2}$-free distilled water can be obtained by either boiling distilled water or by stirring it vigorously under vacuum in a sealed suction flask. If boiling is used, the water should be cooled to room temperature before use. $\mathrm{CO}_{2}$-free distilled water should be sealed in an air-tight container to protect it from atmospheric $\mathrm{CO}_{2}$.)

Gently pack soil to the bulk density content determined for that particular soil at field sampling, as indicated by the line marked on the outside of the jar. For the Catlin silt loam, use a bulk density of $1.2 \mathrm{~g} \mathrm{~cm}^{-3}$.

Pre-incubate soils by placing each jar in its respective incubator (i.e., assigned temperature treatment) for 1 week. Keep lids on except when aerating (by removing lids) for $1 \mathrm{~h}$ each day. Over the weekends, a thin polyethylene sheet (such as Saran $\operatorname{wrap}^{(\mathrm{TM})}$ ) can be secured with a rubber band to allow some gaseous diffusion with minimal moisture loss. However, polyethylene sheets should not be used continuously because anaerobic conditions may eventually develop, altering $\mathrm{N}$ transformations.

Correct for any moisture loss every 1 to 3 days (depending on temperature) by weighing each jar + soil and adding distilled water with the plant mister. (As a guideline, it was found that soils at $35^{\circ} \mathrm{C}$ declined from one-third bar to one bar in just 3 days when uncovered for $2 \mathrm{~h}$ per day.) Because drying rate will depend on temperature, airflow, humidity, etc., vigilance is needed.

Incubation

Weigh and incorporate your manure type into those jars designated to receive manure, in an amount calculated to provide $350 \mathrm{~kg}$ total $\mathrm{N} \mathrm{ha}^{-1}$ incorporated to a $15 \mathrm{~cm}$ depth. Mix unamended soils in the same manner as the amended soils so they all receive equal disturbance. Then gently pack the soil to its original bulk density. The Catlin silt loam with a bulk density of $1.2 \mathrm{~g} \mathrm{~cm}^{-3}$ is used as an example of the calculations needed. For illustration purposes only, assume the manure is $2 \% \mathrm{~N}$ on a dry weight basis.

Soil volume in a hectare furrow slice (hafs):

$$
\frac{10,000 \mathrm{~m}^{2}}{\text { ha }} \times \frac{0.15 \mathrm{~m}}{\text { furrow slice }}=\frac{1500 \mathrm{~m}^{3}}{\text { hafs }}
$$


Calculating oven dry (OD) weight of manure to add to each jar:

$$
\begin{aligned}
& \frac{350 \mathrm{~kg} \mathrm{~N}}{\text { hafs }} \times \frac{\text { hafs }}{1500 \mathrm{~m}^{3}} \times \frac{\mathrm{m}^{3}}{1,000,000 \mathrm{~cm}^{3}} \times \frac{\mathrm{cm}^{3}}{1.2 \mathrm{~g} \mathrm{OD} \mathrm{soil}} \\
& \times \frac{1000 \mathrm{~g} \text { OD soil }}{\mathrm{kg} \mathrm{OD} \mathrm{soil}} \times \frac{100 \mathrm{~kg} \mathrm{OD} \mathrm{manure}}{2 \mathrm{~kg} \mathrm{~N}} \\
& \times \frac{0.250 \mathrm{~kg} \text { OD soil }}{\text { Jar }} \times \frac{1000 \mathrm{~g} \mathrm{OD} \mathrm{manure}}{\mathrm{kg} \mathrm{OD} \mathrm{manure}}=\frac{2.43 \mathrm{~g} \mathrm{OD} \mathrm{manure}}{\text { Jar }}
\end{aligned}
$$

which simplifies to:

$$
\frac{\text { g OD manure }}{\text { Jar }}=\frac{5.83}{(\text { Bulk density } \times \% \text { manure } N)}
$$

The moisture content of the manure must then be taken into account. The manure specific variables therefore include manure total $\mathrm{N}$ content and manure moisture content. The soil specific variable for the above calculation is bulk density. From your manure application rate and manure moisture content, calculate how much water you added with the manure. Account for this manure-derived water when calculating how much water to add to bring your soil to its target $60 \%$ WFPS.

Add distilled water to bring all soil and soil + manure treatments to the gravimetric water content corresponding to 60\% WFPS using Eq. (5). (Place a given jar on a balance and mist with D.I. water until the desired weight is obtained.)

$$
\begin{aligned}
& W F P S=(\Theta \cdot B) /[1-(B / P)] \\
& \Theta=[W F P S \cdot(P-B)] /(B \cdot P)
\end{aligned}
$$

where

WFPS $=$ Water Filled Pore Space, $\%$

$1=$ gravimetric water content, $\%$

$\mathrm{B}=$ Bulk density, $\mathrm{g} \mathrm{cm}^{-3}$

$\mathrm{P}=$ Particle density $=2.65 \mathrm{~g} \mathrm{~cm}^{-3}$.

\section{Moisture Maintenance}

Drill two, $12.5 \mathrm{~mm}$ diameter holes in each jar lid of wetting/drying regime " $\mathrm{b}$ " to promote drying. For both water treatments, weigh jar + soil every 1 to 3 days and record weights. Maintain wetting/drying regime "a" at $60 \%$ WFPS. When water content in wetting/drying regime "b" reaches $30 \%$ WFPS, mist with distilled water to bring soil to $60 \%$ WFPS. 
Sampling Intensity

The first sample date is on the day of manure application (i.e., time $=0$ ). Subsequent sample dates for a given soil and temperature are governed by when the wetting/drying treatment reaches 30\% WFPS. Sample soils receiving the wetting/drying treatment immediately (i.e., within $10 \mathrm{~min}$ ) after re-wetting the soil back to $60 \%$ WFPS. Do this for each of four wetting/drying cycles. On the same date you sample soils receiving the wetting/drying treatment (moisture regime b), sample the corresponding soils maintained at constant water content (moisture regime a). For example, soils incubated at $25^{\circ} \mathrm{C}$ may need sampling one day, and those incubated at $18^{\circ} \mathrm{C}$ may need sampling on another day. In this case, soil at moisture regime a and $25^{\circ} \mathrm{C}$ would be sampled at the same time you sample soil at moisture regime $\mathbf{b}$ at $25^{\circ} \mathrm{C}$. One may also find that soil $\# 1$ at $25^{\circ} \mathrm{C}$ needs sampling at a different date than soil $\# 2$ at $25^{\circ} \mathrm{C}$. In this case, soil \#1 at moisture regimes $\mathbf{a}$ and $\mathbf{b}$ and $25^{\circ} \mathrm{C}$ would be sampled at a different date than soil \#2 at moisture regimes $\mathbf{a}$ and $\mathbf{b}$ and $25^{\circ} \mathrm{C}$ (vigilance in monitoring moisture levels is definitely needed).

\section{Extraction and Analysis}

At each sample date, the following is performed on the $10.0 \mathrm{~g}$ (moist weight) sample: On $5.0 \mathrm{~g}$, determine gravimetric water content. Extract the remaining $5.0 \mathrm{~g}$ (moist weight) with $50 \mathrm{~mL} 2 \mathrm{M} \mathrm{KCl}$ for $60 \mathrm{~min}$ on a wrist-action shaker. Centrifuge or filter the extract. Freeze or acidify extract if analysis cannot be performed within 3 to 4 days. Analyze extract for $\mathrm{NH}_{4}^{+}$and $\mathrm{NO}_{2}^{-}+\mathrm{NO}_{3}^{-}$. Report inorganic $\mathrm{N}$ concentrations on an oven-dry, elemental $\mathrm{N}$ basis. (NOTE: The target weight for maintaining a given water content of each soil or soil + manure will change throughout the study due to sampling. Consequently, the amount of soil removed at each sample date must be accounted for in order to calculate these target weights and therefore maintain moisture regimes at their appropriate levels.)

\section{FIELD STUDY PROTOCOL}

\section{Overview}

The field component is designed to complement the laboratory studies by using the same soils and manures at a given location. Data from the field study therefore provide pseudo-field validation of laboratory based $\mathrm{N}$ availability predictions. In summary, relatively undisturbed soil cores (microplot cylinders) are obtained from the same soil/field area from which the incubation study soil was obtained. Microplot cylinders are constructed with manure-amended and unamended treatments. Cloth bags containing anion exchange resin are held in place at the bottom of each cylinder to capture 
$\mathrm{NO}_{3}^{-}$leaching. All cylinders (enough for the entire study) are then returned to the field. Microplot cylinder soil temperature and water content are continuously measured and recorded with a datalogger. Microplot cylinders are destructively sampled at predetermined intervals. Soil and anion exchange resin from each cylinder are extracted with $\mathrm{KCl}$ and analyzed for $\mathrm{NH}_{4}^{+}$and $\mathrm{NO}_{3}^{-}$. These data can then be compared with the $\mathrm{N}$ availability predictions that are 1) based on the corresponding laboratory study; 2) based on the overall Team's generalized $\mathrm{N}$ availability predictions across soils, manures, and climates; and 3) based on the corresponding field studies across soils, manures, and climates.

\section{Treatments}

The following constitute the Core treatments and procedures that are followed by all participants as a minimum. Additional treatments, analyses, sample dates, etc., may be included at the discretion of each scientist.

Core treatments consist of 1 soil-site X,2 manure additions (with and without) $\mathrm{X}, 6$ replications $\mathrm{X}, 8$ sample dates $=96$ experimental units (minimum). (It would be most desirable to use two soil-sites, as this would add substantially to each location's database, publishing potential, etc. Although the soil/resin extraction workload is spread out over different sample dates, having two soil-sites would double the number of cylinders to construct, treat, etc. Locations with available resources may want to consider this possibility.)

A separate set of 12 microplot cylinders (fulfilling the Core requirement) is collected and returned to the lab at $0,3,7,14,21,28,49$, and 70 days after manure application. Using a datalogger, soil temperature and water content are continuously monitored in microplot cylinders that remain in the ground for the duration of the study. As specified below, $7.6 \mathrm{~cm}$ diameter cylinders are suggested, especially for those locations using stony soils. However, other cylinder diameters may be warranted based on stone content, soil variability, and material availability. These modifications can be made at the discretion of each participant.

\section{Materials}

- 102 cylinders (96 for treatments, 3 for monitoring temperature, and 3 for monitoring water) constructed with $7.6 \mathrm{~cm}$ inside diameter, $8.3 \mathrm{~cm}$ outside diameter PVC pipe, each cut to $17.1 \mathrm{~cm}$ long. Pipe should be available at many local hardware stores, but could be ordered from Portland Plastic Pipe $^{1}, 53$ Winslow St., Portland, ME 04101-1940, 207-774-0364.

${ }^{1}$ Any use of trade names is to provide specific information, and does not constitute endorsement by the authors or by USDA-ARS. 
- 306 polyethylene caps (min.), with $8.3 \mathrm{~cm}$ inside diameter; also available from Portland Plastic Pipe ${ }^{1}$.

- $5 \mathrm{~kg}$ (moist wt.) anion exchange resin [J.T. Baker ${ }^{1}$ : A-554, $\mathrm{Cl}^{-}$form, Type 2, Beads (16-50 mesh)].

- Polyester fabric, enough to make about $200,12.7 \mathrm{~cm}$ diameter pieces.

- Nylon hose, enough to make about $102,10 \mathrm{~cm} \times 10 \mathrm{~cm}$ squares. (Nylon should all be the same color and thickness. Beige, support hose approximates the color of many soils, as well as provides extra durability.)

- 102 rubber bands

- Soil core sampler with drop hammer attachment for $7.6 \mathrm{~cm}$ diameter cores (i.e., the PVC pipe). Can be manufactured by Don Towne at Hackett Machine Co. ${ }^{1}, 1$ Industrial Plaza, Brewer, ME, 207-989-2466.

- Datalogger equipped with soil temperature and soil water sensors that can fit within the microplot cylinders.

- Sewing machine

\section{Procedures}

Microplot Cylinder Construction

Cylinders are constructed from $7.6 \mathrm{~cm}$ inside diameter PVC pipe with a wall thickness of $0.32 \mathrm{~cm}$. Cut $17.1 \mathrm{~cm}$ lengths of the pipe. It is suggested to use a miter chop saw, but a manual hacksaw would work. Mark one end of each cylinder as the top and measure down $1.9 \mathrm{~cm}$ from that end along the inside of the cylinder. Place marks at this point around the inside circumference of the cylinder to denote where the top level of the soil will be. This measurement may vary depending on the soil and manure used and should be determined beforehand (see Treatment Application).

Resin bags are made out of polyester fabric. Cut $12.7 \mathrm{~cm}$ diameter rounds of fabric and sew two partially together to form an open-ended bag with an inner diameter of $8.9 \mathrm{~cm}$. Fill each bag with $25 \mathrm{~g}$ (dry weight) anion exchange resin. Sew the open end of each bag shut and store in D.I. water.

Perforated plastic caps are used at the bottom of each cylinder to hold the soil and resin bags in place, while allowing drainage out of the cylinder. For 102 caps, drill five evenly spaced $0.3 \mathrm{~cm}$ diameter holes in each cap.

\section{Microplot Cylinder Soil Collection}

Cores of an unfertilized soil should be collected from the same site/soil series used for the laboratory incubation study. Following that protocol, the soil should not have received manure in the last 10 years.

Drive cylinders into the soil using either a) a sliding drop hammer (Figure 1), b) a mallet and a wood block, or c) a hydraulic core sampler. Drop hammers are more effective when there is an abundance of stones 


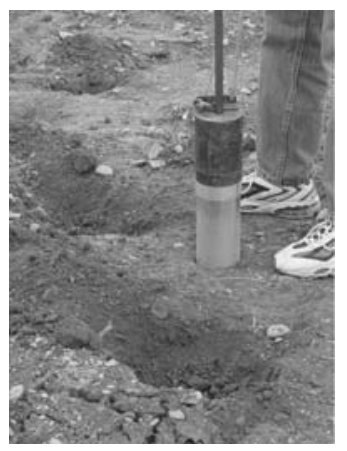

Figure 1. Driving core sampler with sliding drop hammer.

because stones tend to fracture the PVC pipe. The top level of the soil should be even with the marks previously placed along the inside circumference of the cylinder, $1.9 \mathrm{~cm}$ from its top edge. This will allow enough room for repacking soil that has been removed and mixed with manure at the time of manure application. Again, since soils and manures are different and may not repack the same way, some experimentation may be necessary in order to determine the ideal level of soil. Carefully lift each core from the ground using a shovel underneath the core to prevent spillage (Fig. 2). Level off the soil at the bottom of the cylinder using a knife or spatula so it is even with the bottom edge of the cylinder. Each core should contain the same volume of soil, as many of our calculations will be based on knowing the exact amount of soil present. Consequently, it is important to take care to prevent soil spillage out of the cylinder when leveling the bottom. Cap off both ends, mark the top of the cylinders, store upright (Fig. 3), and return them to the lab.

\section{Treatment Application}

In the laboratory, remove the surface $4 \mathrm{~cm}$ of soil from a given cylinder into a container. Place the container and soil on a balance, tare, and add the appropriate amount of manure that provides an application rate of $350 \mathrm{~kg} \mathrm{~N}^{-1}$

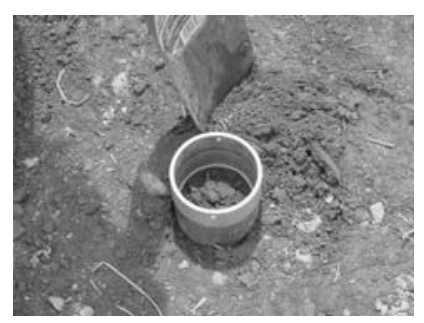

Figure 2. Preparing to dig out core containing microplot cylinder. 


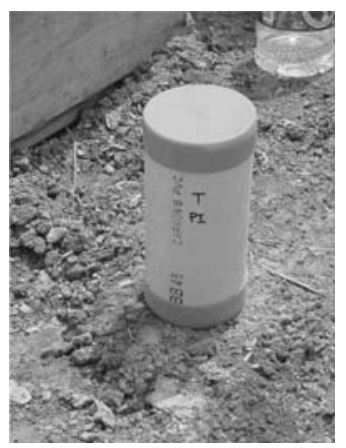

Figure 3. Microplot cylinder capped at both ends $(\mathrm{T}=\mathrm{Top})$.

applied to a $15 \mathrm{~cm}$ depth. [This is the same application rate used in the incubation studies. An example calculation is provided in Eqns. (6)-(8).] After thoroughly mixing the manure into the soil, gently pack the mixture back into the cylinder. Control (unamended) soils are handled in the same manner (i.e., removing, stirring, and repacking the surface $4 \mathrm{~cm}$ ), but without adding manure. Soil should not be packed so firmly that would promote denitrification. Ideally, the level of repacked soil should be even with the top edge of the cylinder. If the volume of the mixed soil is such that it is difficult to fit back in the cylinder, or if it does not fill the cylinder, then the level of soil in the cylinders needs to be adjusted at the time the cylinders are collected. This is why it is recommended that this be determined beforehand (see Microplot Cylinder Construction).

Once soil is repacked into the top of the cylinder, place a plastic cap on the top and invert the cylinder. Then place a D.I. water-saturated resin bag on the cylinder, secured with a perforated plastic end cap. Press slightly to ensure soil to resin contact, but do not press so firmly as to compact the soil. Reinvert the cylinder so its top is now facing upwards. Replace the top plastic cap with a thin sheet of polyethylene (such as Saran wrap ${ }^{(\mathrm{TM})}$ ) secured by a rubber band. This is temporarily placed to minimize excessive drying.

The first sample is at day 0 and should be processed immediately after the treatments are applied in the lab (see Collecting and Processing Cylinders). There may not be enough time to treat the entire study's cylinders and process the first sample in one day. In this case, all cylinders, except for the first sample, can be treated on one day. Cylinders for the first sample can then be treated and processed on the next day.

Manure Application Example

The following example is provided for calculating how much manure to add to a given cylinder. This example is given for a cylinder with an internal diameter 
of $7.6 \mathrm{~cm}$ and contains a $15 \mathrm{~cm}$ depth of soil. Manure is assumed to be $2 \% \mathrm{~N}$ on a dry weight basis. (OD denotes Oven Dry.)

Soil volume in a hectare furrow slice (hafs):

$$
\frac{10,000 \mathrm{~m}^{2}}{\text { ha }} \times \frac{0.15 \mathrm{~m}}{\text { furrow slice }}=1500 \mathrm{~m}^{3} \cdot \text { hafs }^{-1}
$$

Calculating oven-dry (OD) weight of manure to add to each cylinder:

$$
\begin{aligned}
& \text { Cylinder Volume }=\pi r^{2} \mathrm{~h}=(3.14) \times(3.8 \mathrm{~cm})^{2} \times(15 \mathrm{~cm}) \\
& =680.12 \mathrm{~cm}^{3} \\
& \begin{array}{l}
\frac{350 \mathrm{~kg} \mathrm{~N}}{\mathrm{hafs}} \times \frac{\text { hafs }}{1500 \mathrm{~m}^{3}} \times \frac{\mathrm{m}^{3}}{1,000,000 \mathrm{~cm}^{3}} \times \frac{680.12 \mathrm{~cm}^{3} \text { soil }}{\text { cylinder }} \\
\times \frac{100 \mathrm{~kg} \text { OD manure }}{2 \mathrm{~kg} \mathrm{~N}} \times \frac{1000 \mathrm{~g} \mathrm{OD} \text { manure }}{\mathrm{kg} \mathrm{OD} \mathrm{manure}} \\
=\frac{7.94 \mathrm{~g} \text { OD manure }}{\text { cylinder }}
\end{array}
\end{aligned}
$$

Adjust this application rate by accounting for the moisture content of undried manure.

\section{Microplot Cylinder Installation}

Transport cylinders to the field, remembering to handle them in a manner that minimizes operator-induced artifacts on $\mathrm{N}$ cycling processes (i.e., realize they are biologically active. . take care to keep them in the shade, etc.). Install cylinders, except for the first sample date, in an area close to where the cores were initially collected from the field. Use soil ("can" or "bucket") augers (approx. $7.6 \mathrm{~cm}$ diameter) to dig appropriately sized holes for the cores. Space holes approximately $30 \mathrm{~cm}$ apart so cylinders can be removed at a later date without disturbing nearby cylinders. Remove the polyethylene sheet from the top of the cylinder. Cover the cylinder top with a thin square sheet of nylon hose secured with a rubber band. Insert cylinders into the holes so the cylinder base firmly contacts the soil below (to promote drainage) and so the cylinder top is level with the surrounding soil. It is suggested to place cylinders in blocks by sample date, as this will make it much easier to know which cylinders to remove later. Pack soil tightly around the cylinder, taking care to ensure good contact between the outside cylinder wall and the surrounding soil. Ideally, this should be done on the day of treatment application, but cylinders can be installed at a later date if weather and time considerations interfere. If application and installation dates differ, then record cylinder storage time and storage temperature. 
Microplot Cylinder Maintenance

Cylinders should be maintained in a fallow condition, otherwise, plant uptake of $\mathrm{N}$ would have to be measured. They can be maintained fallow by frequent inspection and simply hand-weeding any weeds that emerge. Raindrop splash can also cause additional soil to be deposited into the cylinder, which would introduce additional variability. This can be minimized by frequent inspection (especially after a rain storm), and scraping off any soil deposited on the nylon hose cover.

\section{Cylinders for Monitoring Temperature and Water}

Six separate cylinders should be collected for monitoring cylinder soil temperature (3) and cylinder soil water content (3). Continuous monitoring is recommended with a datalogger, such as that available from Campbell Scientific ${ }^{1}$.

For monitoring cylinder soil temperature, drill an approximately $6 \mathrm{~mm}$ dia. hole in the cylinder wall at the $7.6 \mathrm{~cm}$ soil depth. Cover hole with tape until it arrives at the field. Insert a previously prepared thermocouple midway through the cylinder. Insert the cylinder in the same area used for the other microplot cylinders.

For monitoring soil water content, place a moisture sensor at the $7.6 \mathrm{~cm}$ depth. (We use gypsum blocks, recognizing they are not perfect.) Install these cylinders in the same area used for the other microplot cylinders.

Additional soil temperature and water measurements can be taken from other cylinders, from soil outside of the cylinders, and at other depths, if desired.

\section{Collecting and Processing Cylinders}

After the first sample date, cylinders need to be removed from the field at 3, 7, $14,21,28,49$, and 70 days after manure application. Use a shovel or trowel to dig out around one side of a cylinder then work it carefully out of the ground. Care should be used not to dislodge the plastic end caps that hold resin bags in place, or to throw soil onto the top of surrounding cylinders while digging. Place the cylinders in a cooler containing ice packs (insulate ice packs from cylinders with thick paper/cardboard so soil adjacent to an ice pack does not freeze) and transport them to the lab for processing.

Remove resin bags from the bottom of each cylinder and keep cool and moist until all soil is processed. Remove all soil from a given cylinder and thoroughly mix. It is important to account for all soil in the cylinder, thus care should be taken that none is lost. Cylinders from the first sample date (day 0) do not need to contain resin bags. 
Sieve about $50 \mathrm{~g}$ of mixed soil using a clean, preweighed, $2 \mathrm{~mm}$ sieve. If the soil is wet and sticking to the sieve, weigh the soiled sieve. Use the sieved soil for extraction and gravimetric water determination.

Extract soil by shaking $10.00 \mathrm{~g}$ field moist soil for $60 \mathrm{~min}$ with $100 \mathrm{~mL}$ $2 M \mathrm{KCl}$ on a wrist-action shaker. Centrifuge or filter the extract. This study centrifuged extracts and then poured them through a 270-mesh screen to remove particulate matter that might clog the tubes on the analyzer. Refrigerate extracts if they can be analyzed within the next 3 to 4 days. Otherwise, freeze or acidify them. Analyze extracts for $\mathrm{NH}^{+}$ and $\mathrm{NO}_{2}^{-}+\mathrm{NO}_{3}^{-}$. Report inorganic $\mathrm{N}$ concentrations on an oven-dry, elemental $\mathrm{N}$ basis.

Dry $20.00 \mathrm{~g}$ soil at $105^{\circ} \mathrm{C}$ for $48 \mathrm{~h}$ for gravimetric water determination. Place remaining sieved soil, stones remaining on the sieve, and unsieved soil plus stones into a tared paper bag. Weigh the bag of soil and stones. To this weight, add the weight of soil adhering to the sieve, the weight of soil extracted, and the weight of soil dried for gravimetric water. The bag of soil can be wet sieved at a later date to obtain stone $(>2 \mathrm{~mm})$ weights and volumes. (Data will be expressed in $\mathrm{mg} \mathrm{N} \mathrm{kg}^{-1}$ soil. Consequently, stone content is needed so stone volume can be subtracted from cylinder volume to calculate the actual quantity of soil to which the manure was added.)

Once all soils are processed, cut resin bags open with scissors. Place a funnel over a $1000 \mathrm{~mL}$ flask and pour entire contents of the resin bag into the flask. Turn the resin bag inside out over the funnel and brush the remaining resin beads into the flask. Extract resin beads by shaking with $250 \mathrm{~mL}$ of $2 \mathrm{M} \mathrm{KCl}$ for $60 \mathrm{~min}$. Centrifuge or filter the extracts. Handle (e.g., freeze) and analyze resin extracts following the same procedure used for soil extracts. As this is an anion exchange resin, these extracts need only be analyzed for $\mathrm{NO}_{2}^{-}+\mathrm{NO}_{3}^{-}$.

\section{SUMMARY}

A team of USDA-ARS scientists is conducting a nationally coordinated research project to develop, validate, and employ predictive relationships that quantify the impacts of key soil, environmental, and soil X environmental factors on manure Nmin. The research team's overall approach is to characterize selected agricultural soils and manures from each participant's location; conduct laboratory incubation studies across a range of soils, manures, and controlled climatic parameters; compile all laboratory data to develop generalized predictions of manure Nmin; and to validate Nmin predictions under field conditions across manures, soils, and environments. Detailed protocols were developed and employed by all participants to ensure data compatibility that allows comparison across locations and compilation into a national database on manure $\mathrm{N}$ mineralization. These protocols are offered here for others wishing to contribute to this effort or 
for others conducting research on similar processes in laboratory or complementary laboratory-field-based projects.

\section{REFERENCES}

Griffin, T.S., Honeycutt, C.W., and He, Z. (2003) Changes in soil phosphorus from manure application. Soil Science Society of America Journal, 67: 645-653.

Grossman, R.B. and Reinsch, T.G. (2002) Bulk density and linear extensibility. In Methods of Soil Analysis, Part 4; Dane, J.H. and Topp, G.C., Eds.; SSSA Book Series No. 5, Soil Science Society of America, Inc: Madison, Wisconsin, 201-228.

Linn, D.M. and Doran, J.W. (1984) Effect of water-filled pore space on carbon dioxide and nitrous oxide production in tilled and nontilled soils. Soil Science Society of America Journal, 48: 1267-1272.

USDA Census of Agriculture. (1997) http://www.nass.usda.gov/census/\#1997 (accessed 1997). 